\title{
"Implementasi Cerita yang Efektif, Kreatif-interaktif dan Menyenangkan Bagi Sekolah Minggu"
}

\author{
Oleh: \\ Risnalti Alvionita \\ Mahasiswa Institut Agama Kristen Negeri Toraja \\ Email: Risnaltyalvionita@gmail.com
}

\begin{abstract}
Abstrak
Gereja memiliki tugas untuk membina setiap warga gerejanya. Sekolah minggu merupakan program pembinaan warga gereja bagi anak-anak untuk mengenalkan mereka kepada Tuhan Yesus. Dalam pendidikan sekolah minggu mengunakan beberapa cerita yang efektif, kreatif-interaktif dan menyenangkan agar anak sekolah minggu tidak bosan pergi ke gereja untu beribadah. Gereja sebagai pusat pendidikan Kristen bertanggung jawab melaksanakan pendidikan Kristen seutuhnya bagi seluruh jemaat baik terhadap orang dewasa maupun terhadap anak-anak.
\end{abstract}

Kata kunci : sekolah Minggu, gereja, efektif, kreatif-interaktif, menyenangkan

\section{Pendahuluan}

Globalisasi dunia beranjak kepada era yang dikenal dengan sebutan era Revolusi Industri 4.0. Revolusi Industri 4.0 merupakan perubahan industri ke-4, hal ini menyebabkan banyak perubahan yaitu optimasi robot dan mesin dalam setiap dunia industri dengan sistem konektivitas dan digitalisasinya. Revolusi Industri 4.0. berdampak besar kepada kehidupan bangsa Indonesia terkhusus pada bidang pendidikan. ${ }^{1}$

\footnotetext{
${ }^{1}$ Daniel Fajar Panuntun et al., Model Ibadah Sekolah Minggu Kreatif-Interaktif Bagi Generasi Alfa Di Gereja Toraja, Bia : Jurnal Teologi dan pendidikan Kristen Kontekstual 2, no. 2 (2019): 194.
} 
Sekolah Minggu adalah suatu bentuk pelayanan pembinaan warga gereja terhadap anak-anak. Tujuannya untuk mengenalkan mereka kepada Yesus, hingga mereka menerima-Nya sebagai Tuhan dan Juruselamatnya secara pribadi. Tugas utama seorang guru sekolah minggu adalah mengenalkan anak kepada pelayanan sekolah minggu ialah cerita yang efektif, kreatif, dan menyenangkan. ${ }^{2}$

Pendidikan merupakan hal yang sangat penting bagi kelangsungan hidup manusia, apalagi belajar merupakan aktivitas yang dikerjakan sepanjang hayat. Pendidikan adalah sesuatu yang diturunalihkan oleh satu generasi selanjutnya yang di dalamnya mengandung muatan pengetahuan, bahkan tak jarang ideologi tertentu. ${ }^{3}$ Dalam pendidikan sekolah minggu mengunakan beberapa cerita yang efektif, kreatif-interaktif dan menyenangkan agar anak sekolah minggu tidak bosan pergi ke gereja untu beribadah.

\section{Rumusan Masalah}

Bagaimana mengimplementasikan cerita yang efektik, kreatif, dan menyenangkan bagi Sekolah Minggu

\section{Tujuan dan manfaat}

Menemukan cara bercerita yang aktif, kreatif-interakti dan menyenangkan bagi sekolah minggu. Manfaatnya adalah mempermudah guru sekolah minggu memahami anak-anak saat bercerita agar anak-anak sekolah minggu tidak bosan dalam beribadah.

\section{Pembahasan}

Sekolah minggu adalah suatu bentuk pembinaan warga gereja yang ditunjukkan untuk anak-anak. Sekolah Minggu merupakan pelayanan yang sangat erat kaitannya dengan gereja. Pada intinya bentuk pelayanan dari sekolah minggu ini adalah anak-anak dikumpulkan dan diajar Firman Tuhan pada hari minggu dan kegiatan ini dilaksanakan oleh Gereja. Prioritas utamanya gereja adalah penyelamatan orang yang

\footnotetext{
${ }^{2}$ Kezia Yemima and Sarah Stefani, Khotbah Eksposisi Narasi Yang Kreatif Dan Kontekstual Bagi Anak-Anak Generasi Z, Gamaliel : Teologi dan Praktika 1, no. 2(2019): 73.

${ }^{3}$ Yohanes Krismantyo Susanta, Tradisi Pendidikan Iman Anak Dalam Perjanjian Lama, Bia : Jurnal Teologi dan Pendidikan Kristen Kontekstual 2, no. 2 (2019): 140.
} 
terhilang dan pembangunan tubuh Kristus. Artinya Gereja harus membuat pendengar mengerti akan kebenaran dengan berbagai cara. Jika pendengar tersebut adalah anak-anak sekolah minggu maka Injil harus disampaikan dengan cara sedemikian rupa agar anakanak mengerti dan menyerahkan dirinya kepada Tuhan Yesus. Berdasarkan sistem Westhill, rentang usia anak-anak yang dilayani dalam sekolah minggu adalah 0-14 tahun, artinyaanak-anak usia 5-6 tahun masuk kedalam kategori usia yang dilayani dalam sekolah minggu. Tiga aturan pokok dalam sistem ini adalah mempelajari seluruh aspek perkembangan anak, guru bekerja dan mengembangkan potensi anak, dan menyusun tata ibadah yang sesuai dengan anak. Anak-anak merupakan pribadi yang multidimensional, memiliki beberapa aspek dalam kehidupannya yaitu emosi, rohani, mental, kehendak dan jasmani. Kebutuhan anak ialah terpenuhinya seluruh kebutuhan setiap aspek kehidupannya. ${ }^{4}$

Gereja sebagai pusat pendidikan Kristen bertanggung jawab melaksanakan pendidikan Kristen seutuhnya bagi seluruh jemaat baik terhadap orang dewasa maupun terhadap anak-anak. Sekolah Minggu merupakan salah satu bentuk layanan pendidikan Kristen yang dilaksanakan oleh gereja dalam rangka pembinaan kerohanian anak agar dapat mengenal Yesus Kristus sebagai Tuhan dan Juruselamatnya. Harry M. Pilland berkata sekolah minggu merupakan wadah pelayanan yang penting dalam menjangkau orangorang bagi Kristus dan mengembangkan mereka menjadi seperti Dia. Senada dengan itu, Lawrence O. Richard, berkata bahwa Sekolah Minggu adalah wadah yang memberi pelayanan kepada anak-anak dengan menjalankan fungsinya sebagai suatu komunitas iman bagi anak-anak yang di dalamnya anak belajar tentang Firman Tuhan untuk semakin mengenal karya Kristus dalam hidupnya. ${ }^{5}$

\section{Bercerita yang efektif}

Salah satu cara efektif menyampaikan cerita adalah dengan membacakannya. Ada cerita-cerita tertentu yang sering lebih berhasil disampaikan secara demikian ketimbang

\footnotetext{
${ }^{4}$ Kezia Yemima and Sarah Stefani, Khotbah Eksposisi Narasi Yang Kreatif Dan Kontekstual Bagi Anak-Anak Generasi Z, Gamaliel : Teologi dan Praktika 1, no. 2(2019): 76-77.

${ }^{5}$ Daniel Fajar Panuntun et al., Model Ibadah Sekolah Minggu Kreatif-Interaktif Bagi Generasi Alfa Di Gereja Toraja, Bia : Jurnal Teologi dan pendidikan Kristen Kontekstual 2, no. 2 (2019):
} 
disampaikan secara lisan, apalagi bila dibacakan dengan ekspresi yang baik. Cara ini baik untuk kelas dengan jumlah nara didik yang sedikit. Posisi guru harus berada di tempat yang dapat dilihat oleh nara didik, apalagi bila ia menggunakan gambar sewaktu bercerita. Keutuhan yang lain, bila jenis cerita yang mau disampaikan berisi dialog, maka cerita dapat dituliskan dan kelas dibagi menjadi beberapa kelompok. Tiap kelompok diberi peran sesuai dengan naskah yang ada. Keuntungan dari cara ini, nara didik dapat langsung bertanya tentang informasi yang ia dengar. Cara menyampaikan cerita dengan menggunakan papan flanel sudah bisa dilakukan sejak dahulu, namun masih tetap menarik bagi nara didik di berbagai usia. Selain guru dengan menggunakan gambar di papan flanel, maka nara didik juga dapat menggunkan papan dan gambar untuk mengulangi cerita dengan memakai bahasanya sendiri. Banyak cara yang digunakan untuk menyampaikan cerita yang efektif diantaranya drama, musik, gerakan tubuh, rekaman, menulis cerita dan lain-lain. ${ }^{6}$

\section{Cerita yang Kreatif-interaktif}

Analisis interaktif adalah analisis dengan menggunakan teknik pengumpulan data, reduksi data, dan penarikan kesimpulan dari data-data yang baik telah didapatkan. Pengumpulan data telah dideskripsikan dalam bentuk narasi kemudian dilakukan proses reduksi hingga didapatkan penarikan kesimpulan. Model kreatif-interaktif merupakan model yang didasari untuk menciptakan model pembelajaran yang menarik sehingga murid-murid sekolah minggu senantiasa datang dan termotivasi untuk mengikuti sekolah minggu. Model ini secara kreatif menggunakan pemanfaatan permainan (game) dan pemanfaatan kemajuan teknologi informasi sehingga diharapkan adanya suatu interaksi yang menyenangkan antara Guru dan murid sekolah minggu. Harapan dan dampak yang dihasilkan adalah murid sekolah minggu termotivasi untuk belajar kepada murid-murid sekolah minggu. Model ini tidak menutup kemungkinan untuk dipraktikkan ataupun diimplementasikan pada sekolah minggu gereja Toraja. ${ }^{7}$

\footnotetext{
${ }^{6}$ Ruth S. Kadarmanto, Tuntunlah Ke Jalan yang Benar Panduan Mengajar Anak di Jemaat, penerbit : BPK Gunung Mulia (2012): 89.

${ }^{7}$ Daniel Fajar Panuntun et al., Model Ibadah Sekolah Minggu Kreatif-Interaktif Bagi Generasi Alfa Di Gereja Toraja, Bia : Jurnal Teologi dan pendidikan Kristen Kontekstual 2, no. 2 (2019):
} 


\section{Cerita yang menyenangkan}

Bercerita menyenangkan bagi sekolah minggu haruslah dilakukan dengan tetap memperhatikan suasana pembelajaran. Menurut penelitian anak-anak menjadi berminat untuk belajar jika topik yang dibahas sedapat mungkin dihubungkan dengan pengalaman mereka dan disesuaikan dengan alam berfikir mereka. ${ }^{8}$ Misalnya ketika guru sekolah minggu mengajar di depan anak-anak sekolah minggu, guru harus memberikan gambaran yang mereka pahami dan mengerti.

\section{Peran orang tua}

Orang tua memiliki peran yang besar bahkan menjadi perpanjangan tangan Allah untuk mendidik anak-anak yang dipercayakan kepada mereka. Terkait peran orangtua sebagai wakil Allah tersebut, maka orang tua berkewajiban mendidik anak-anak yang dipercayakan Allah di tengah keluarga. Sebab kelangsungan bangsa bergantung pada anak-anak (keturunan) sebagai generasi penerus di masa mendatang. Orang tua tersebut bukan sekadar bertanggung jawab mendidik anak, tetapi mereka sendiri pun harus belajar sepanjang hayat mereka. Hal itu ditegaskan oleh Robert Boehlke bahwa ruang lingkup pendidikan agama Yahudi sungguh mengejutkan. Ia bukanlah suatu usaha sambilan saja, melainkan inti dari kegiatan sehari-hari yang lazim dilakukan. untuk memenuhi syarat pendidikan itu, para orangtua sendiri wajib menjadi pelajar seumur hidup. Orang tua memiliki kewajiban untuk mengajar anak-anak mereka tentang hukum Allah dengan kata teladan. Selain itu, terdapat berbagai kutipan ayat dalam PL yang menunjuk pada tugas untuk memberikan pendidikan kepada anak-anak misalnya yang terdapat dalam kita Ulangan, “ Ingatlah kepada zaaman dahulu kala, perhatikanlah tahuntahun keturunan yang lalu, tanyakanlah kepada ayahmu, maka ia memberitahukannya kepadamu, kepada para tua-tuamu, maka mereka mengatakannya kepadamu "(U1. 32:7). Tidaklah cukup bagi orang tua mengajar dengan kata-kata. Anak-anak harus menjadikan diri mereka sendiri teladan sebagai pengikut Kristus yang setia kepada anak-anak mereka. Keluarga tentu saja hidup dalam komunitas yaitu gereja. Namun orang tua tidak bisa melepaskan tanggung jawab dan meyerahkan tugas tersebut pada institusi gereja.

\footnotetext{
${ }^{8}$ www.com Metode PAIKEM, Di undu pada tanggal 16 Maret 2020.
} 
Gereja perlu melakukan pembinaan iman anak sambil terus menjalin komunikasi dengan para orangtua sebab hal tersebut merupakan tanggung jawab bersama. ${ }^{9}$

\section{Kesimpulan}

Berdasarkan pembahasan di atas saya menyimbpulkan bahwa sekolah minggu merupakan adalah suatu bentuk pelayanan pembinaan warga gereja terhadap anak-anak. Dalam pendidikan sekolah minggu mengunakan beberapa cerita yang efektif, kreatifinteraktif dan menyenangkan agar anak sekolah minggu tidak bosan pergi ke gereja untu beribadah. Orang tua memiliki peran yang besar bahkan menjadi perpanjangan tangan Allah untuk mendidik anak-anak yang dipercayakan kepada mereka.

\section{Saran}

Penulis memberi saran kepada para guru sekolah minggu di gereja-gereja agar memanfaatkan model atau cara bercerita yang efektif, kreatif-interaktif dan menyenangkan di depan sekolah minggu agar anak sekolah minggu tidak bosan beriadah.

\section{Referensi}

Daniel Fajar Panuntun et al., Model Ibadah Sekolah Minggu Kreatif-Interaktif Bagi Generasi Alfa Di Gereja Toraja, Bia : Jurnal Teologi dan pendidikan Kristen Kontekstual 2, no. 2 (2019).

Ruth S. Kadarmanto, Tuntunlah Ke Jalan yang Benar Panduan Mengajar Anak di Jemaat, penerbit : BPK Gunung Mulia (2012).

www.com Metode PAIKEM, Di undu pada tanggal 16 Maret 2020.

Kezia Yemima and Sarah Stefani, Khotbah Eksposisi Narasi Yang Kreatif Dan Kontekstual Bagi Anak-Anak Generasi Z, Gamaliel : Teologi dan Praktika 1, no. 2(2019).

Yohanes Krismantyo Susanta, Tradisi Pendidikan Iman Anak Dalam Perjanjian Lama, Bia : Jurnal Teologi dan Pendidikan Kristen Kontekstual 2, no. 2 (2019).

${ }^{9}$ Yohanes Krismantyo Susanta, Tradisi Pendidikan Iman Anak Dalam Perjanjian Lama, Bia : Jurnal Teologi dan Pendidikan Kristen Kontekstual 2, no. 2 (2019):147-149. 
